\title{
Osteoporosis: epidemiology, clinical and biological aspects
}

\author{
A Reda ${ }^{1 *}$, M G Bartoletti ${ }^{2}$ \\ From de Senectute: Age and Health Forum \\ Catanzaro, Italy. 5-7 December 2009
}

Osteoporosis is the most prevalent disease of bone metabolism, characterized by fragility and risk of fracture. The frequency of fractures increases with age and the cost of this disease increases more and more. Every thirty seconds someone in European Union suffers a hip fracture as a result of osteoporosis. The fractures of wrist, hip and vertebra are the most prevalent. Now the bone quality is more important than the BMD. The evaluation of patient begins with the analysis of risk fracture: age, familiarity of fragility fracture, calcium and vitamin D intake, BMI less than nineteen, early menopause, smoking, alcohol abuse, risk of falls. The people with at least one of these risk factors have to do the analysis of BMD, by DEXA at the femur or ultrasound at the fingers or the heel. The relationship between the BMD and the clinical situation of patient is important in order to understand who has to do the blood tests and the xray of dorsal and lumbar spine in LL. The blood exams need to differentiate the types of osteoporosis, to value the bone markers and vitamin $\mathrm{D}$. I remember that the vitamin $\mathrm{D}$ level is important for the calcium, the bone and the muscle metabolism and for the good action of the drugs of osteoporosis. The X-ray of dorsal and lumbar spine needs to show the presence of vertebral fractures. We have to calculate the level of fracture and the SDI (Spine deformity index) by Genant's SQ scale. At the end I show the therapy of osteoporosis and its criterion.

\section{Author details \\ ${ }^{1}$ U.O. Fkt Distretto Sanitario Rogliano, ASP Cosenza, Italy . ${ }^{2}$ Centro di riabilitazione "Biolife", Cosenza, Italy.}

Published: 19 May 2010
doi:10.1186/1471-2318-10-S1-L71

Cite this article as: Reda and Bartoletti: Osteoporosis: epidemiology, clinical and biological aspects. BMC Geriatrics 2010 10(Suppl 1):L71.
Submit your next manuscript to BioMed Central and take full advantage of:

- Convenient online submission

- Thorough peer review

- No space constraints or color figure charges

- Immediate publication on acceptance

- Inclusion in PubMed, CAS, Scopus and Google Scholar

- Research which is freely available for redistribution

Submit your manuscript at www.biomedcentral.com/submit
C Biomed Central

'U.O. Fkt Distretto Sanitario Rogliano, ASP Cosenza, Italy 